\title{
VALUES OF YOUNG EMPLOYEES: Z-GENERATION PERCEPTION
}

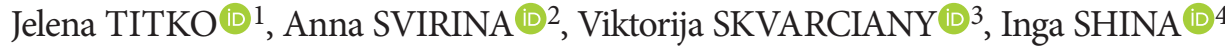 \\ 1, ${ }^{4}$ EKA University of Applied Sciences, Riga, Latvia \\ ${ }^{2}$ Department of Economics and Management, Department of Engineering Economics, \\ Kazan National Research Technical University named after A. N. Tupolev, Kazan, Russia \\ ${ }^{3}$ Department of Economics Engineering, Faculty of Business Management, \\ Vilnius Gediminas Technical University, Vilnius, Lithuania

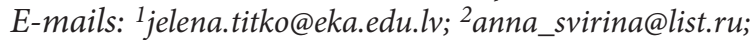 \\ 3viktorija.skvarciany@vgtu.lt (corresponding author); ${ }^{4}$ inga.shina@eka.edu.lv
}

Received 07 September 2019; accepted 29 October 2019

\begin{abstract}
The current paper aims to analyse the importance of values of young employees now and in five years period. In order to achieve the aim, the questionnaire consisting of fifty statements was developed and disseminated between the Latvian students. The sample size was 392, which shows that the results represent the whole populations. For data processing, factor analysis was chosen as a tool. The data factorability was assessed via Bartlett's Test of Sphericity, Kaiser-MyerOlkin (KMO) statistic, initial estimates of communality and the anti-image correlation matrix. The factors were extracted via principal axis factoring (PAF). The number of factors was determined by the scree plot/Kaiser's rule and was equal to five in both cases. The results showed the for the young employees the essential values today are those connected to the personality trait. However, in five years, the essential values would be those that are linked to professional development.
\end{abstract}

Keywords: Z-Generation, values, factor analysis, professional development, employment.

JEL Classification: E24, M51, J13, A13.

\section{Introduction}

Z-Generation is the one that is discussed by several scientists. Many scholars pay their attention to technology and innovation adoption by representatives of Z-Generation (Quintanilha 2017, Roblek et al. 2019). However, there are only few studies concentrating on Z-Generations infusion to the labour market (Bejtkovsky 2013, Ruzsa 2018). Moreover, it was challenging to find any researches on the employees' representing Z-Generation values. Because of that, the idea of the current study was developed.

The idea of the current research emerged due to the lack of the studies, analysing the Z-Generation employees' values, and the personal engagement of the authors into the study process within management programmes. Being actively involved in teaching, we are interested in delivering relevant knowledge to our students in order to increase their competitiveness in the labour market. The focus of the given study is a values mismatch. What is essential for young employees and does it correspond to the critical matters for employers?

Hence, the goal of the research was to evaluate the importance of values and behavioural aspects perceived by young employees. In order to achieve the research goal, 392 Latvian students from different educational fields were surveyed. The research instrument was the authors' developed questionnaire, the structure of which is described in the methodological section. Pre-determined values and behavioural aspects were offered to respondents for evaluation. Respondents were asked to evaluate the importance of each of 50 statements for themselves and employers, today and in the nearest future.

The current paper reflects the results of the survey, focusing only on students' answers regarding themselves. Data

*Corresponding author. E-mail: viktorija.skvarciany@vgtu.lt 
processing was done in Excel and SPSS environment, applying such techniques as frequency analysis, as well as dimension reduction employing factor analysis.

The research results contribute to the scientific literature in the field of Z-Generations studies focused on the values from the employees' perspective. The developed questionnaire could be used for getting information regarding the values of young employees in different countries.

\section{Literature review}

Now, six generations are being defined by the researchers (Becton et al. 2014): 1) veterans/builders/traditionalists; 2) baby-boomers; 3) generation $\mathrm{X}$; 4) generation $\mathrm{Y}$ (Millennials/me generation); 5) generation $\mathrm{Z}$; 6) generation Alpha (Facebook generation/digital natives).

The most frequently the attention is focused on generational differences (Bencsik et al. 2016, Cennamo and Gardner 2011, Twenge et al. 2010). While existing studies are oriented towards concluding Z-Generation's behaviour based on comparisons to previous generations, in this paper, we undertake a different approach and assess $\mathrm{Z}$-Generation from their views on their current state and desired future.

Z-Generation, covering the ones born after the year 2000 , currently became an object for many studies that follow intensive research on Millennials. Scholars outline, that Z-Generation youngsters are digital natives (Popescu et al. 2019), born with the social web and "technology as their identity" (Singh and Dangmei 2016). According to mainstream research, this generation's values lead to the following preferences in the workplace: they are looking for transparency and self-reliance in their job (Mileski et al. 2016); their focus in work environment is value-oriented, and provide professional and personal development (Bridge 2015); looking for ambitious work goals as this generation intends to make a difference (Marron 2015).

Besides described above, other studies note significant behavioural differences between Z-Generation and Millennials, that within the values part include the following: higher trust to the opinion of previous generations (Mileski et al. 2016), more pursuit towards privacy and higher level of risk aversion (Seemiller and Grace 2016), digitalisation of the whole lifecycle (Barron 2014) Hence, one can await that Z-Generation would be more oriented towards the values of success, privacy, security and making a difference; however, the set of existing experiments evaluating the needs of this generation had come to diverse conclusions, which leads to the investigation on generation's goal orientation.

Due to analysed controversy, Z-Generation awakes several conclusions on its proposed workplace behaviour, that has not been proven yet as the Z-people are at most 18 years old and have not yet entered their full-time jobs. Still, researchers argue that this generation would have the skills to work on a few tasks at the same time without losing efficiency (Adecco 2019, Ozkan and Solmaz 2015). Moreover, they would demonstrate self-confidence above average due to higher innovation and creativity (Half 2015, Roblek et al. 2019) that lead to their intention to work alone rather than be involved in the teamwork - despite their ability to make the most out of globalisation (Addor 2011). At the same time, this generation respects authority and does not intend to question it (Tulgan 2013); hence the majority of them enter job environment without the prior development of soft skills, requesting such development from the employer (Tulgan 2013). This assessment of workplace development leads Z-Generation to midsize companies or international corporations, where professional and personal development usually is a part of career management (Half 2015). Finally, Z-Generation is reported to be more realistic in their demand towards employer compared to previous generations (Tulgan 2013).

These features, along with biological differences reported by medical research (average attention concentration of 7 seconds compared to 15 seconds on generation $\mathrm{X}$, ability to process multilevel data with the help of natively used technology, higher efficiency in multitasking environment (Bridge 2015, Half 2015, Tulgan 2013) led to speculative conclusions on Z-Generation's possible behaviours in the workplace. However, it is quite questionable and underresearched whether Z-Generation carries out such commonly named values as technology orientation, desire to proceed with multiple tasks, individualisation (as opposite to teamwork), ambitious goals, personal development and professional growth, environmental concern (West 2014).

\section{Methodology}

To find out what values are and will be necessary for young employees - the authors surveyed Latvian students. The authors' developed questionnaire was used. The first variant of the questionnaire was developed within the framework of the state programme "Strategic planning of talents in the Republic of Tatarstan for 2015-2020", specifically in the process of the development and approbation of the monitoring system. The suggested evaluation/monitoring system was based on the methodology, developed by the Barrett Values Centre based on the analysis of the World Bank's data about organisational culture management data. The above-mentioned evaluation system incorporated approximately 100 values (personal and organisational) grouped into seven categories of values required for a company's viability.

For the purposes of the current research, the questionnaire was simplified - only 50 values were remained and offered to the respondents for assessment. Others, with a high level of similarity, were excluded. 
The questionnaire consisted of two main sections: section I - respondent profile; section II - values and behavioural aspects. The structure of the questionnaire is presented in Table 1.

Table 1. Structure of the questionnaire (source: developed by authors)

\begin{tabular}{|c|c|c|}
\hline Section I & Respondent profile & Comments \\
\hline Q1 & Gender & $\begin{array}{l}\text { Closed: } 2 \\
\text { alternatives }\end{array}$ \\
\hline Q2 & Age & Opened \\
\hline Q3 & Place of birth & Opened \\
\hline Q4 & Employment status & $\begin{array}{l}\text { Closed: } 3 \\
\text { alternatives }\end{array}$ \\
\hline Section II & Values and behavioural aspects & Comments \\
\hline Q1 & $\begin{array}{l}\text { What students consider being } \\
\text { important today? }\end{array}$ & \multirow{4}{*}{$\begin{array}{l}50 \text { statements } \\
\text { for evaluation; } \\
5 \text {-point scale }\end{array}$} \\
\hline Q2 & $\begin{array}{l}\text { What students consider being } \\
\text { important in } 5 \text { years? }\end{array}$ & \\
\hline Q3 & $\begin{array}{l}\text { What employers consider } \\
\text { being important today (on the } \\
\text { viewpoint of students)? }\end{array}$ & \\
\hline Q4 & $\begin{array}{l}\text { What employers consider being } \\
\text { important in } 5 \text { years (on the } \\
\text { viewpoint of students)? }\end{array}$ & \\
\hline
\end{tabular}

Responses on the questions Q3 and Q4 of section II were not analysed within the current research.

After the questionnaire development, the method of the respondents' view assessment had to be chosen. Actually, scholars working in the field of social sciences use various scales: for instance, Stapel scale (Ahmed et al. 2014, Sreejesh et al. 2014), semantic differential scale (Ciabuca 2015, Kahveci 2015), Likert scale (Ariani 2017, Breffle et al. 2011, Mouselli and Khalifa 2017, Petsky et al. 2012). However, the Likert scale method is the most popular one because of its ease of use. Hence, the interviewees were offered to use Likert 5 -point scale for grading. The respondents ought to evaluate the statements on a five-scale basis, i.e. the respondents had to indicate the level of his/her consent/disagreement with the submitted statement, where "1" indicated "absolutely not important" and "5" - "critically important". Statements offered to respondents for evaluation, as well as their labels used in data analysis, are presented in Table 2.

All the statements presented in Table 2 had to be answered in two different concepts. The respondents had to evaluate which of the values are essential for them to now and which would be significant in five years. The sample consisted of 392 Latvian students with a different educational background from different universities. Distribution of the respondents according to the gender criterion was $32 \%$ and $68 \%$, females and males, respectively. The average age of the respondents was 23 years. Most of the respondents were from Riga (41\%).
Table 2. Statements for evaluation (source: developed by authors)

\begin{tabular}{|c|c|c|c|}
\hline No. & & No. & \\
\hline 1 & $\begin{array}{l}\text { Encouraging and } \\
\text { supporting of my } \\
\text { talent }\end{array}$ & 26 & Teamwork \\
\hline 2 & $\begin{array}{l}\text { Identifying strengths; } \\
\text { recognition of } \\
\text { an employee's } \\
\text { achievements }\end{array}$ & 27 & Results' orientation \\
\hline 3 & Enthusiasm; initiative & 28 & Adaptability \\
\hline 4 & Creativity & 29 & Practice \\
\hline 5 & $\begin{array}{l}\text { Balance of the work/ } \\
\text { home/free time }\end{array}$ & 30 & $\begin{array}{l}\text { Ability to act in } \\
\text { uncertain conditions }\end{array}$ \\
\hline 6 & Trustworthiness & 31 & Authority \\
\hline 7 & $\begin{array}{l}\text { Attention to me; } \\
\text { empowerment of my } \\
\text { abilities }\end{array}$ & 32 & Ability to set goals \\
\hline 8 & $\begin{array}{l}\text { Opportunity to show } \\
\text { myself }\end{array}$ & 33 & $\begin{array}{l}\text { Ability to act according } \\
\text { to plan }\end{array}$ \\
\hline 9 & $\begin{array}{l}\text { Balance of the } \\
\text { spiritual / physical } \\
\text { / intellectual / } \\
\text { emotional }\end{array}$ & 34 & Decision making skills \\
\hline 10 & $\begin{array}{l}\text { Continuous } \\
\text { improvement and } \\
\text { training }\end{array}$ & 35 & Responsibility \\
\hline 11 & Control; exactingness & 36 & Success \\
\hline 12 & Variety of tasks & 37 & The trust \\
\hline 13 & $\begin{array}{l}\text { Opportunity for } \\
\text { specialization }\end{array}$ & 38 & Honesty \\
\hline 14 & $\begin{array}{l}\text { Competitive spirit; } \\
\text { opportunity to } \\
\text { overtake others }\end{array}$ & 39 & Ambitiousness \\
\hline 15 & Independence & 40 & Image and reputation \\
\hline 16 & $\begin{array}{l}\text { My personal } \\
\text { development plan }\end{array}$ & 41 & Ability to convince \\
\hline 17 & Ethics & 42 & Ability to use chances \\
\hline 18 & $\begin{array}{l}\text { Support, explanations; } \\
\text { tips }\end{array}$ & 43 & Social guarantees \\
\hline 19 & $\begin{array}{l}\text { Experience, } \\
\text { masterliness }\end{array}$ & 44 & Listening skills \\
\hline 20 & Joint discussion & 45 & Process' orientation \\
\hline 21 & Financial stability & 46 & Long-term perspective \\
\hline 22 & Perspective & 47 & Communicability \\
\hline 23 & $\begin{array}{l}\text { Mutual help and } \\
\text { cooperation }\end{array}$ & 48 & Attentiveness \\
\hline 24 & $\begin{array}{l}\text { Ability to change } \\
\text { things }\end{array}$ & 49 & Work on yourself \\
\hline 25 & Quality of work & 50 & Self-presentation \\
\hline
\end{tabular}


$62 \%$ of respondents are currently employed; $31 \%$ - were employed in the past, and 7\% have never worked and are not employed now. Initial analysis was performed by calculating "average" and applying the procedure of ranking.

The number of factors was quite high, hence, additionally to ranking procedure dimension redaction was used. Dimension reduction was performed for both Q1 and Q2 data sets using factor analysis - specifically Principal Component Analysis (PCA). In fact, factor analysis is widely used by scholars analysing working in the field of socials sciences and researching a significant amount of data (Durana et al. 2019, Lentjusenkova et al. 2016).

First of all, the data ought to be tested for suitability for factor analysis. For that issue, many scientists working in the field of educational sciences choose Kaiser-Meyer-Olkin (KMO) test and Bartlett's Test of Sphericity (BTS) (Jamil et al. 2015, Kurtuldu and Bulut 2017, Moto et al. 2018, Sever 2014).

Bartlett's Test of Sphericity is used in order to find out if the collected answers are valid for the factor analysis. If the Bartlett's Sphericity c2 is lower than the significance level $\alpha$, it means that the data could be employed for the factor analysis. Bartlett's Sphericity c2 is calculated using formula (1).

$$
\chi^{2}=\frac{\left(\sum_{i=1}^{k} n_{i}-k\right) \ln s_{p}^{2}-\sum_{i=1}^{k}\left(n_{i}-1\right) \ln s_{i}^{2}}{1+\frac{1}{3(k-1)}\left(\sum_{i=1}^{k} \frac{1}{n_{i}-1}-\frac{1}{\sum_{i=1}^{k} n_{i}-k}\right)},
$$

where: $s_{i}^{2}$ - pooled estimate for the variance; $k$ - number of samples; $n_{i}$ - sample size.

Kaiser-Meyer-Olkin Measure (KMO) is employed in order to test the data adequacy. The higher is the KMO value; the higher is factor analysis validation. The KMO is calculated using the below-presented formula (2).

$$
K M O=\frac{\sum \sum_{i \neq j} r_{i j}^{2}}{\sum \sum_{i \neq j} r_{i j}^{2}+\sum \sum_{i \neq j} a_{i j}^{2}},
$$

where: $r_{i j}$ - correlation coefficient variables $X_{i}$ and $X_{j ;} a_{i j}$ the partial correlation coefficient of the variables $X_{i}$ and $X_{j}$.

All the statistical analysis procedures were performed using SPSS 26.0 environment.

\section{Empirical findings}

First, all the data was ranked by "average". According to the results of the ranking procedure, the essential values and behavioural aspects today on the viewpoint of students are "Quality of work", "Work on yourself", "Honesty", "Responsibility" and "Opportunity to show yourself". Least important in students' perception are "Encouraging and supporting of my talent", "Control; exactingness", "Competitive spirit; opportunity to overtake others", "Joint discussion" and "Authority".
However, the distribution of the ranks of today's values differs from the ranks of values necessary in the future. "Quality of work", "Responsibility" and "Work on yourself" remained in top-five. However, "financial stability" was placed in the first position. The fourth place was given to "Decision-making skills". Least important values did not change their positions on the list.

Comparing results with other value studies, the authors consider that at least to a certain extent the results are aligned with the results from the previous studies. For instance, Bencsik et al. (2016) characterize $Z$ generation representatives attitudes to teamwork and collaboration, as follows:

- Teamwork - "on a virtual level (only if forced)";

- Relationship - "virtual and superficial".

Analyzing today's attitudes, "teamwork" was placed at $37^{\text {th }}$ place, "mutual help and cooperation" and "joint discussion" (which can be considered as substitutes for "relationship") at $38^{\text {th }}$ and $49^{\text {th }}$ place, respectively. Importance tomorrow is even less $-39^{\text {th }}, 40^{\text {th }}$ and $50^{\text {th }}$ place, respectively. Thus, Z-people appreciates independence. By the way, "independence" was on $10^{\text {th }}$ place for today and $9^{\text {th }}$ place for tomorrow.

Bridge (2015) stated that Gen Z prefers work environment with professional development opportunities. "Continuous improvement and training" was placed on the $9^{\text {th }}$ position on today's value list. Only $21^{\text {st }}$ place among tomorrow values, but it can be explained with students' higher perceived experience/knowledge in their future.

Another example - McKinsey survey (Francis and Hoefel 2018). The McKinsey experts revealed "Gen Z behaviours, all anchored in one element: this generation's search for truth." Assuming the synonymity between "truth" and "honesty", this was also confirmed in the current study: the $3^{\text {rd }}$ and the $6^{\text {th }}$ place, respectively in "today" and "tomorrow" list.

The ranking itself, probably, cannot lead to particular conclusions, considering a large number of elements. However, these results are useful in the next stage of analysis - dimension reduction.

Before the dimension reduction procedure, the data were tested for suitability for factor analysis. The results of the performed tests are provided in Table 3.

KMO value was computed in order to understand whether the data set was appropriate for the analysis and the results were 0,913 for section II - Q1 data and 0,904 for Q2 data (see Table 3). The KMO value shows that the data was appropriate for the factor analysis according to a very high test result. Bartlett's test of Sphericity was significant both for Q1 and Q2 data with chi-square test values of 7381,906 $(\mathrm{df}=1225, \mathrm{p}=0,000)$ and 6744,177 $(\mathrm{df}=1225, \mathrm{p}=0,000)$ respectively, demonstrating that factor analysis was adequate to the observed data.

Factor analysis of Q1 data. The initial stage of PCA (based on eigenvalues greater than 1 ) yielded 12 components containing 1 to 4 elements with factor loadings higher than 
0.5. Following the experience of other researchers, who fix the number of factors (usually basing the decision on interpretability criterion), the authors of the given research fixed the number at 5 . The resulting rotated component matrix is presented in Table 4 (elements with factor loadings less than 0,5 were removed).

Factor analysis of Q2 data. The number of components was fixed at five in order to get consistent results. The resulting rotated component matrix is presented in Table 5 (elements with factor loadings less than 0,5 were removed).

As it could be seen from Table 4, twenty-five elements were left in the questionnaire, and five factors were extracted. According to the results, the most important values for young employees now are those combined in the first factor: honesty, listening skills, ability to convince, trust, decisionmaking skills, self-presentation, and attentiveness. Actually,
Table 3. KMO and Bartlett's Test (source: authors' calculations)

\begin{tabular}{|c|c|c|c|}
\hline \multirow{4}{*}{$\begin{array}{l}\text { Section II } \\
\text { Q1 data }\end{array}$} & \multicolumn{2}{|c|}{$\begin{array}{l}\text { Kaiser-Meyer-Olkin (KMO) } \\
\text { Measure of Sampling Adequacy }\end{array}$} & 0.913 \\
\hline & \multirow{3}{*}{$\begin{array}{l}\text { Bartlett's Test of } \\
\text { Sphericity }\end{array}$} & $\begin{array}{l}\text { Approx. Chi- } \\
\text { Square }\end{array}$ & 7381,906 \\
\hline & & df & 1225 \\
\hline & & Sig. & 0.000 \\
\hline \multirow{4}{*}{$\begin{array}{l}\text { Section II } \\
\text { Q2 data }\end{array}$} & \multicolumn{2}{|c|}{$\begin{array}{l}\text { Kaiser-Meyer-Olkin (KMO) Measure } \\
\text { of Sampling Adequacy }\end{array}$} & 0.904 \\
\hline & $\begin{array}{l}\text { Bartlett's Test of } \\
\text { Sphericity }\end{array}$ & $\begin{array}{l}\text { Approx. Chi- } \\
\text { Square }\end{array}$ & 6744,177 \\
\hline & & $\mathrm{df}$ & 1225 \\
\hline & & Sig. & 0.000 \\
\hline
\end{tabular}

Table 4. PCA analysis of section II - Q1 data (source: authors' calculations)

\begin{tabular}{|c|c|c|c|c|c|}
\hline & & & mpone & & \\
\hline & $\mathrm{F} 1$ & F2 & F3 & $\mathrm{F} 4$ & F5 \\
\hline Honesty (statement 3) & 0.620 & & & & \\
\hline Listening skills (statement 20) & 0.602 & & & & \\
\hline Ability to convince (statement 35 ) & 0.564 & & & & \\
\hline Trust (statement 11) & 0.560 & & & & \\
\hline Decision-making skills (statement 6) & 0.548 & & & & \\
\hline Responsibility (statement 4 ) & 0.543 & & & & \\
\hline Self-presentation (statement 14) & 0.523 & & & & \\
\hline Attentiveness (statement 30) & 0.504 & & & & \\
\hline Trustworthiness (statement 41) & & 0.639 & & & \\
\hline Attention to me; empowerment of my abilities (statement 21) & & 0.604 & & & \\
\hline $\begin{array}{l}\text { Balance of the spiritual/physical/intellectual/emotional (statement } \\
\text { 34) }\end{array}$ & & 0.598 & & & \\
\hline Balance of the work/home/free time (statement 17) & & 0.509 & & & \\
\hline Variety of tasks (statement 42 ) & & 0.503 & & & \\
\hline Encouraging and supporting of my talent (statement 46) & & 0.500 & & & \\
\hline Results' orientation (statement 25) & & & 0.615 & & \\
\hline Experience, masterliness (statement 23) & & & 0.555 & & \\
\hline Adaptability (statement 27) & & & 0.514 & & \\
\hline Enthusiasm; initiative (statement 15) & & & 0.511 & & \\
\hline Continuous improvement and training (statement 9) & & & 0.510 & & \\
\hline Competitive spirit; opportunity to overtake others (statement 48 ) & & & & 0.662 & \\
\hline Authority (statement 50) & & & & 0.641 & \\
\hline Ambitiousness (statement 44) & & & & 0.572 & \\
\hline Social guarantees (statement 33) & & & & & 0.661 \\
\hline Financial stability (statement 7) & & & & & 0.646 \\
\hline Joint discussion (statement 49) & & & & & 0.547 \\
\hline
\end{tabular}


almost all these variables are connected to the skills that are linked to human characteristics, which could be explained by the fact that millennials are more focused on intangible values.

Table 5 presents the result of the factor analysis for section II - Q2 data, i.e. for the values that would be important for young employees in five years. In that case, twenty-six variables/items were left in the questionnaire, and five factors were extracted. The first factor explains about thirty per cent of variance; hence, the values, combined in that factor could be treated as the most essential. Listening skills remain in the first factor; however, other values differ. Additionally, to listening skills, the factor includes Balance of the spiritual/ physical/intellectual/emotional state, ability to change skills, continuous improvement and training, perspective, quality of work, and adaptability.
To sum up, from the viewpoint of the students, representing Z-generation, regarding the values that are vital today, it could be stated that all the values are linked to personal character traits, empathy. However, the values that would be critical in five years are connected to professional development and moving up the career ladder.

\section{Conclusions}

The current study aimed to explore which values are essential for the young employees, representing Z-generation, at the current moment and in five years time period. For gathering the data, the questionnaire containing fifty elements was developed. The students had to answer the same questions considering different time (now and in five years). In both cases, five factors were extracted.

Table 5. PCA analysis of section II - Q2 data (source: authors' calculations)

\begin{tabular}{|c|c|c|c|c|c|}
\hline & & & mpone & & \\
\hline & 1 & 2 & 3 & 4 & 5 \\
\hline $\begin{array}{l}\text { Balance of the spiritual/physical/intellectual/emotional state } \\
\text { (statement 37) }\end{array}$ & 0.668 & & & & \\
\hline Ability to change things (statement 33 ) & 0.598 & & & & \\
\hline Continuous improvement and training (statement 21) & 0.559 & & & & \\
\hline Perspective (statement 15) & 0.554 & & & & \\
\hline Quality of work (statement 2) & 0.549 & & & & \\
\hline My personal development plan (statement 28) & 0.549 & & & & \\
\hline Adaptability (statement 27) & 0.532 & & & & \\
\hline Listening skills (statement 14 ) & 0.502 & & & & \\
\hline Honesty (statement 6) & & 0.640 & & & \\
\hline Self-presentation (statement 12) & & 0.635 & & & \\
\hline Work on yourself (statement 5 ) & & 0.634 & & & \\
\hline Responsibility (statement 3 ) & & 0.586 & & & \\
\hline Decision-making skills (statement 4) & & 0.535 & & & \\
\hline Ability to set goals (statement 16 ) & & 0.507 & & & \\
\hline Encouraging and supporting of my talent (statement 47 ) & & & 0.576 & & \\
\hline Joint discussion (statement 50) & & & 0.558 & & \\
\hline Support, explanations; tips (statement 35) & & & 0.510 & & \\
\hline Social guarantees (statement 20) & & & 0.503 & & \\
\hline Authority (statement 49) & & & & 0.668 & \\
\hline Success (statement 45 ) & & & & 0.584 & \\
\hline Image and reputation (statement 36 ) & & & & 0.556 & \\
\hline Ability to convince (statement 30 ) & & & & 0.556 & \\
\hline Ability to use chances (statement 38 ) & & & & 0.503 & \\
\hline Competitive spirit; opportunity to overtake others (statement 48 ) & & & & & 0.555 \\
\hline Ability to act in uncertain conditions (statement 41 ) & & & & & 0.545 \\
\hline Ability to act according to plan (statement 24 ) & & & & & 0.520 \\
\hline
\end{tabular}


Talking about section II - Q1 dataset, the first involves the values that are connected to personal traits. This factor explains about thirty per cent of variance; hence, the values it combines could be treated as the most essential. The second factor consists of the values that are related to the work environment. The third one includes the values that could be summarised as motivation. The fourth factor could be explained as competitiveness, and the fifth one is related to a comfortable existence.

However, the situation is different if we talk about the values that would be important for students in future (section II - Q1 dataset). In that case, the first factor includes items that are linked to professional development. The second factor involves the values of personal traits. Most of the values of the second factor were included in the first factor in the case of section II - Q1 (today's values) data. The last three factors are almost the same as in the case of section II - Q1 data.

The current study results contribute to scientific researches in the field of values of young employees, representing $\mathrm{Z}$-generation. Apart of the values mentioned in the previous studies, the current research revealed some new ones - for example, "balance of work/home/free time", "opportunity to show me" or "self-presentation". All these values were placed to upper positions both in "today" and "tomorrow" list (today $-17^{\text {th }}, 5^{\text {th }}, 14^{\text {th }}$ and tomorrow $-8^{\text {th }}, 10^{\text {th }}, 12^{\text {th }}$ place, respectively).

The extracted factors are useful for further researches, where the weights for each of the factor are going to be assigned using multi-criteria decision-making methods.

Considering the limitation of the current study (only students' own values were analysed), the next research will be focused on students' current and future perception of employers' values.

\section{References}

Addor ML (2011) Generation Z: What is the future of stakeholder engagement? Institute of Emerging Issues.

Adecco (2019) Generation Z vs. millennials in the workplace http://bit.ly/2Lnamdt

Ahmed SU, Islam Z, Mahtab H, Hasan I (2014) Institutional investment and corporate social performance: linkage towards sustainable development. Corporate Social Responsibility and Environmental Management 21 (1): 1-13. https://doi.org/10.1002/csr.1298

Ariani DW (2017) Why do i study? The mediating effect of motivation and self-regulation on student performance. Business, Management and Education 14 (2): 153-178. https://doi.org/10.3846/bme.2016.329

Becton JB, Walker HJ, Jones-Farmer A (2014) Generational differences in workplace behavior. Journal of Applied Social Psychology 44 (3): 175-189. https://doi.org/10.1111/jasp.12208

Bejtkovsky J (2013) Age management concept - opportunity or threat. In: Soliman KS (Ed.). 22nd IBIMA conference on Creating Global Competitive Economies: 2020 Vision Planning \& Implementation. Rome: IBIMA, 805-813.
Bencsik A, Juhász T, Horváth-Csikós G (2016) Y and Z Generations at Workplaces. Journal of Competitiveness 6 (3): 90-106. https://doi.org/10.7441/joc.2016.03.06

Breffle WS, Morey ER, Thacher JA (2011) A joint latent-class model: combining likert-scale preference statements with choice data to harvest preference heterogeneity. Environmental and Resource Economics 50 (1): 83-110. https://doi.org/10.1007/s10640-011-9463-0

Bridge T (2015) 5 ways the workplace needs to change to get the most out of generation http://bit.ly/2MQZ4Qo

Cennamo L, Gardner D (2011) Generational differences in work values, outcomes and person-organisation values fit. I. EEE Engineering Management Review 39 (2): 24-36. https://doi.org/10.1109/EMR.2011.5876170

Ciabuca A (2015) The development of a semantic differential scale for assessing the perceived image of citizens about Romanian police forces. Procedia - Social and Behavioral Sciences 187: 28-33. https://doi.org/10.1016/j.sbspro.2015.03.006

Durana P, Kliestikova J, Kovacova M (2019) The quality of brand products: expected attributes vs. perceived reality. Economics and Culture 16 (1): 98-107. https://doi.org/10.2478/jec-2019-0011

Francis T, Hoefel F (2018) “True Gen”: Generation Z and its implications for companies. McKinsey \& Company.

Half R (2015) Get ready for generation Z. Maclean's 127 (28): 42-45.

Jamil NI, Baharuddin FN, Maknu TSR (2015) Factors mining in engaging students learning styles using exploratory factor analysis. Procedia Economics and Finance 31: 722-729. https://doi.org/10.1016/S2212-5671(15)01161-2

Kahveci A (2015) Assessing high school students' attitudes toward chemistry with a shortened semantic differential. Chemistry Education Research and Practice 16 (2): 283-292. https://doi.org/10.1039/C4RP00186A

Kurtuldu MK, Bulut D (2017) Development of a self-efficacy scale toward piano lessons. Educational Sciences: Theory \& Practice 17 (3). https://doi.org/10.12738/estp.2017.3.0209

Lentjusenkova O, Titko J, Lapina I (2016) Intellectual capital investments: analysis of the predicted outcomes. In: Simberova I, Zizlavsky O, Milichovsky F (Eds). 21th International Scientific Conference of Smart and Efficient Economy: Preparation for the Future Innovative Economy. Brno, 94-101.

Marron MB (2015) New generations require changes beyond the digital. Journalism \& Mass Communication Educator 70 (2): 123-124. https://doi.org/10.1177/1077695815588912

Mileski M, Scott Kruse C, Lee K, Baar Topinka J (2016) Perceptions of the value of professional networking by undergraduate students in a school of health administration: a pilot study. The Journal of Health Administration Education 33 (3): 461474.

Moto S, Ratanaolarn T, Tuntiwongwanich S, Pimdee P (2018) A Thai junior high school students' 21st century information literacy, media literacy, and ICT literacy skills factor analysis. International Journal of Emerging Technologies in Learning (IJET) 13 (09): 87. https://doi.org/10.3991/ijet.v13i09.8355

Mouselli S, Khalifa B (2017) Entrepreneurship in crisis: the determinants of Syrian students' entrepreneurial intentions. Business, Management and Education 15 (2): 159-173. https://doi.org/10.3846/bme.2017.386

Ozkan M, Solmaz B (2015) Mobile addiction of generation Z and its effects on their social lifes. Procedia - Social and Behavioral Sciences 205: 92-98.

https://doi.org/10.1016/j.sbspro.2015.09.027 
Petsky HL, Cates CJ, Lasserson TJ, Li AM, Turner C, Kynaston JA, Chang AB (2012) A systematic review and meta-analysis: tailoring asthma treatment on eosinophilic markers (exhaled nitric oxide or sputum eosinophils). Thorax 67 (3): 199-208. https://doi.org/10.1136/thx.2010.135574

Popescu D, Popa DM, Cotet BG (2019) Getting ready for Generation $\mathrm{Z}$ students - considerations on $3 \mathrm{D}$ printing curriculum. Propósitos y Representaciones 7 (2): 255-268. https://doi.org/10.20511/pyr2019.v7n2.280

Quintanilha LF (2017) Inovação pedagógica universitária mediada pelo Facebook e YouTube: uma experiência de ensinoaprendizagem direcionado à geração-Z. Educar Em Revista (65): 249-263. https://doi.org/10.1590/0104-4060.50027

Roblek V, Mesko M, Dimovski V, Peterlin J (2019) Smart technologies as social innovation and complex social issues of the Z generation. Kybernetes 48 (1): 91-107. https://doi.org/10.1108/K-09-2017-0356

Ruzsa C (2018) Key characteristics of generation Z and main challenges to be expected in the labor market. In Tonkovic AM, Crnkovic B (Eds.). 7th International Scientific Symposium on Economy of Eastern Croatia - Vision And Growth. Osijek: Sveučilište Josipa Jurja Strossmayera u Osijeku, Ekonomski fakultet u Osijeku, 251-259.
Seemiller C, Grace M (2016) Generation Z Goes to College (1st ed.). San Francisco, CA: Jossey-Bass.

Sever M (2014) Adapting classroom engagement inventory into turkish culture. Egitim ve Bilim 39 (176): 171-182. https://doi.org/10.15390/EB.2014.3627

Singh AP, Dangmei J (2016) Understanding the generation Z: the future workforce. South-Asian Journal of Multidisciplinary Studies 3 (3).

Sreejesh S, Mohapatra S, Anusree MR (2014) Business research methods. Cham: Springer International Publishing. https://doi.org/10.1007/978-3-319-00539-3

Tulgan B (2013) Meet generation Z: The second generation within the giant „Millennial” cohort. RainmakerThinking.

Twenge JM, Campbell SM, Hoffman BJ, Lance CE (2010) Generational differences in work Values: leisure and extrinsic values increasing, social and intrinsic values decreasing. Journal of Management 36 (5): 1117-1142. https://doi.org/10.1177/0149206309352246

West M (2014) What manufacturers need to know about generation Z. Manufacturing Engineering 153 (1): 168-168. 